\title{
PRODUKSI DAN ANALISIS DAYA TERIMA ABON IKAN LAYANG SEBAGAI PANGAN FUNGSIONAL
}

\section{PRODUCTION AND ANALYSIS OF ACCEPTABILITY OF SHREDDED FISH AS FUNCTIONAL FOOD}

\author{
Ain Widyani Surgawi ${ }^{1}$, Saifuddin Sirajuddin ${ }^{1}$, Nurhaedar Jafar ${ }^{1}$, Aminuddin Syam ${ }^{1}$, \\ Sabaria Manti Battung ${ }^{1}$
}

(Email/Hp: awidyano@gmail.com/085341951329)

${ }^{1}$ Program Studi Ilmu Gizi, Fakultas Kesehatan Masyarakat, Universitas Hasanuddin, Makassar

\begin{abstract}
ABSTRAK
Pendahuluan: Gaya hidup terutama berpengaruh pada pola konsumsi makanan menyebabkan timbulnya penyakit degeneratif yang termasuk dalam penyakit tidak menular sebagai pembunuh nomor satu terbanyak. Abon ikan layang hadir sebagai salah satu alternatif sebagai pangan fungsional. Tujuan: Penelitian ini bertujuan menganalisis daya terima 3 formula produk abon ikan layang. Bahan dan Metode Penelitian ini dilakukan pada 8 panelis terlatih dengan uji mutu hedonik dan 25 panelis tidak terlatih dengan uji hedonik. Pengolahan data dan analisis menggunakan software SPSS dan disajikan dalam bentuk tabel, grafik, dan teks naratif. Hasil: Hasil penelitian menunjukkan bahwa terdapat pengaruh yang signifikan terhdap daya terima abon ikan layang. Berdasarkan hasil analisis statistik empat parameter pada panelis terlatih bahwa hanya aroma $(p=0,024)$ dan warna $(p=0,003)$ memiliki pengaruh yang signifikan terhadap daya terima abon ikan layang. Sementara pada panelis tidak terlatih, semua parameter warna $(p=0,000)$, aroma $(p=0,000)$, tekstur $(p=0,000)$ dan rasa $(p=0,000)$ memberikan pengaruh yang signifikan terhadap daya abon ikan layang. Kesimpulan: Adapun untuk formula terpilih yang akan diuji secara lanjut dengan uji kandungan zat gizi makro dan mikro, uji kandungan omega 3 dan uji daya simpan adalah formula 3
\end{abstract}

\section{Kata kunci : daya terima, abon, ikan layang}

ABSTRACT
Introduction: Lifestyle mainly influences food consumption patterns causing degenerative diseases which are included in non-communicable diseases as the number one killer. Shredded flying fish is present as an alternative as functional food. Methods: This study aims to analyze the acceptability of 3 formulas of shredded fish products. This research was conducted on 8 panelists trained with hedonic quality test and 25 panelists not trained with hedonic test. Data processing and analysis using SPSS software and presented in the form of tables, graphs, and narrative text. Results: The results showed that there was a significant influence on the acceptability of shredded floating fish. Based on the results of the statistical analysis of the four parameters in the trained panelists that only the aroma $(p=0.024)$ and color $(p=0.003)$ had a significant effect on the acceptability of shredded flying fish. While the panelists were not trained, all color parameters $(\mathrm{p}=0,000)$, aroma $(\mathrm{p}=0,000)$, texture ( $\mathrm{p}$ $=0,000)$ and taste $(p=0,000)$ had a significant influence on the power of shredded flying fish. Conclusion: As for the selected formula that will be tested further by testing the macro and micro nutrient content, the omega 3 content test and the shelf life test are formula 3 


\section{Keywords : acceptability, shredded, flying fish} PENDAHULUAN

Berubahnya gaya hidup baik yang terjadi dikota kota besar maupun di pedesaan berpengaruh pada pola hidup dan terutama pula berpengaruh pada pola konsumsi makanan. ${ }^{1}$ Masyarakat cenderung mengonsumsi makanan tinggi kalori, lemak, dan kolesterol. ${ }^{1}$ Kebiasan hidup demkian tersebut yang tidak dibarengi dengan olahraga, serta seringnya konsumsi alkohol dan merokok, juga termasuk penggunaan obat obatan yang menimbulkan efek samping menjadi kebiasaan bagi sebagian masyarakat pada saat ini. ${ }^{1}$

Pangan merupakan komoditas penting karena pemenuhannya berlandaskan hak asasi setiap rakyat indonesia sebagaimana yang dinyatakan dalam UU No. 7 Tahun 1996 tentang pangan. ${ }^{2 .}$ Kualitas sumber daya manusia dan ketahanan bangsa Indonesia ditentukan oleh kecukupan pangan. ${ }^{3}$ Oleh karenanya, untuk mendapatkan atau memiliki manusia manusia yang berkualitas, pangan harus dipastikan cukup tersedia, merata, aman, bermutu dan bergizi, beragam serta tak lupa hal yang paling penting adalah terjangkau oleh daya beli masyarakat. $^{3}$

Isu pangan fungsional sudah sangat popular belakangan ini. Mengingat hasil hasil penelitian yang menunjukkan peranan senyawa senyawa zat gizi dalam bahan pangan yang memiliki fungsi tertentu dalam menjaga kesehatan. ${ }^{1}$. Menurut Badan POM (2011), pangan fungsional adalah pangan yang secara alami maupun telah melalui proses mengandung satu atau lebih senyawa yang berdasarkan kajian kajian ilmiah dianggap mempunyai fungsi fungsi fisiologis yang bermanfaat bagi kesehatan. ${ }^{4}$ Pangan fungsional dikonsumsi mirip dengan makanan dan minuman pada umumnya, memiliki penampakan, warna, rasa, tekstur dan aroma yang dapat diterima serta tidak memberikan efek samping terhadap metabolisme zat gizi lainnya jika digunakan dalam jumlah lazim. Pangan fungsional tidak berbentuk kapsul, tablet, atau bubuk. ${ }^{4}$

Tingginya laju produksi bahan pangan serta tingginya kebutuhan konsumen membuat produksi pangan yang besar besaran terjadi. ${ }^{5}$ Namun, pangan pangan tersebut memiiki keterbatasan waktu penyimpanan. Salah satu cara yang dilakukan untuk memperpanjang masa simpan pangan adalah dengan penganekaragaman olahan pangan. ${ }^{5} \mathrm{Hal}$ ini juga dapat meningkatkan nilai tambah pada pangan tersebut, misalnya peningkatan kandungan kimia dalam hal ini zat gizi dan juga peningkatan mutu pangan itu sendiri. ${ }^{5}$ Salah satu produk penganekaragaman yang sudah dikenal luas di masyarakat adalah abon. ${ }^{5}$ Abon bisa menjadi salah satu lauk alternatif yang bisa dikunsumsi dengan masa simpan yang cukup lama. ${ }^{5}$ Namun, salah satu faktor yang berperan penting dalam ketersediaan produk abon ikan layang ini adalah daya terima. ${ }^{6}$ Tujuan uji penerimaan adalah untuk mengetahui apakah suatu komoditi atau sifat sensori tertentu dapat diterima oleh masyarakat. ${ }^{6}$ Walaupun sutau komoditi atau bahan pangan fungsional memiliki kandungan-kandungan gizi yang banyak, akan tetapi jika tidak disukai dan tidak diterima oleh masyarakat, makanan atau minuman tersebut tetap saja tidak memiliki nilai ${ }^{6}$

\section{BAHAN DAN METODE}

Jenis penelitian yang digunakan adalah penelitian Observasional deskriptif. Penelitian ini akan dilakukan pada bulan Mei-Juni tahun 2019. Tempat pelaksanaan penelitian dilakukan di Fakultas Kesehatan Masyarakat Universitas Hasanuddin. Pembuatan abon ikan layang 
dilakukan di Laboratorium Kuliner FKM Unhas. Resep abon ikan layang didasarkan pada modifikasi dari berbagai sumber penelitian dan jurnal, adapun tahapannya adalah sebagai berikut.

a. Disaingi dan dipisahkan daging ikan layang dari kepala dan perutnya

b. Disiapkan kukusan dan ikan layang dikukus hingga dagingnya lunak dan mudah diurai

c. Dipisahkan daging ikan layang dari tulangnya lalu disuwir menjadi serabut

d. diblender bumbu halus yang terdiri dari serai, daun salam, ketumbar, gula, garam, bawang merah, bawang putih, dan lengkuas

e. dimasak hasil suwiran ikan layang bersama santan dan bumbu halus

f. disangrai hingga kering

Abon ikan layang dikemas menjadi 3 formula dengan penambahan beberapa bahan tambahan sebagai berikut:

a. Formula 1: daging ikan layang 2,5 kg, serah $25 \mathrm{gr}$, daun salam $25 \mathrm{gr}$, garam 87,5 gr, gula 187,5 gr, bawang merah 25 gr, bawang putih $37,5 \mathrm{gr}$, ketumbar $12,5 \mathrm{gr}$, lengkuas 12,5 gr, san santan 109,37 ml

b. Formula 2: daging ikan layang 2,5 kg, serah 50 gr, daun salam 50 gr, garam 175 gr, gula 375 gr, bawang merah 50 gr, bawang putih 75 gr, ketumbar 25 gr, lengkuas 25 gr, santan $218,75 \mathrm{ml}$

c. Formula 3: daging ikan layang $2,5 \mathrm{~kg}$, serah $100 \mathrm{gr}$, daun salam $100 \mathrm{gr}$, garam $350 \mathrm{gr}$, gula 750 gr, bawang merah 100 gr, bawang putih 150 gr, ketumbar 50 gr, lengkuas 50 gr, santan $437,5 \mathrm{ml}$

Untuk pengujian daya terima dilakukan pada mahasiswa FKM Unhas yang berada pada lokasi pembuatan produk sebagai panelis tidak terlatih dan dipilih secara acak, untuk panelis terlatih dilakukan pada dosen Fakultas Teknik jurusan tata boga Universitas Negeri Makassar. Data skoring hasil pengisian scoresheet akan diolah secara elektronik software pengolah data excel. Perhitungan presentase penerimaan produk pada adalah sebagai berikut.

$$
\begin{aligned}
& \text { Skor Tertinggi }=\frac{(\text { Jumlah panelis } x \text { kategori tertinggi })}{\text { Skor maksimal }} \times 100 \% \\
& \text { Skor terendah }=\frac{(\text { Jumlah panelis } x \text { kategori terendah })}{\text { Skor maksimal }} \times 100 \% \\
& \text { Interval } \quad=\frac{(\text { Skor tertinggi-Skor terendah })}{\text { Jumlah Kategori }}
\end{aligned}
$$

\begin{tabular}{|c|c|c|c|c|}
\hline \multirow{2}{*}{ Skor \% } & \multicolumn{4}{|c|}{ Parameter } \\
\hline & warna & aroma & rasa & Tekstur \\
\hline $20-35,99$ & Sangat terang & Tidak harum & Pahit & Sangat kasar \\
\hline $36-51,99$ & Terang & Biasa & Hambar & Kasar \\
\hline $52-67,99$ & Agak terang & Agak harum & Netral/biasa & Normal \\
\hline $68-83,99$ & Biasa/netral & harum & Gurih & Agak Halus \\
\hline $84-100$ & kecoklatan & Sangat harum & Sangat gurih & Sangat halus \\
\hline
\end{tabular}

Kriteria interpretasi skor produk abon ikan layang berdasarkan tiap parameter oleh panelis terlatih

Kriteria interpretasi skor produk abon ikan layang berdasarkan tiap parameter oleh panelis tidak terlatih: 
$20 \%-35,99 \%=$ Tidak Suka (Tidak diterima)

$36 \%-51,99 \%=$ Kurang Suka (Tidak diterima)

$52 \%-67,99 \%=$ Biasa $($ Diterima $)$

$68 \%-83,99 \%=$ Suka $($ Diterima)

$84 \%-100 \%=$ Sangat Suka (Diterima)

Data yang telah dianalisis disajikan dengan deskriptif dalam bentuk tabel, grafik, dan narasi untuk membahas hasil penelitian-

\section{HASIL}

Adapun hasil penelitian yang telah dilakukan bahwa pada variabel warna panelis terlatih memilih formula 3 (740) sebagai formula yang terpilih dengan skor nilai 31 atau $77,5 \%$ pencapaian. Sedangkan panelis tidak terlatih memilih formula 3 (740) sebagai formula yang terpilih dengan skor nilai 91 atau 72,8\% pencapaian. Berdasarkan perhitungan skala likert, formula tersebut dinilai disukai.

Tabel 1. Daya terima abon ikan layang oleh panelis terlatih berdasarkan parameter warna

\begin{tabular}{cccccc}
\hline Formula & $\begin{array}{c}\text { Jumlah } \\
\text { Panelis }\end{array}$ & $\begin{array}{c}\text { Skor } \\
\text { maksimum }\end{array}$ & $\begin{array}{c}\text { Jumlah } \\
\text { Skor }\end{array}$ & $\begin{array}{c}\text { \% } \\
\text { Capaian }\end{array}$ & Ket \\
\hline F1 (803) & 8 & 40 & 24 & 60 & Agak terang \\
F2 (956) & 8 & 40 & 26 & 65 & Netral/biasa \\
F3 (740) & 8 & 40 & 31 & 77,5 & Netral/biasa \\
\hline
\end{tabular}

Sumber: Data Primer, 2019

Tabel 2. Daya terima abon ikan layang oleh panelis tidak terlatih berdasarkan parameter warna

\begin{tabular}{cccccc}
\hline Formula & $\begin{array}{c}\text { Jumlah } \\
\text { Panelis }\end{array}$ & $\begin{array}{c}\text { Skor } \\
\text { maksimum }\end{array}$ & $\begin{array}{c}\text { Jumlah } \\
\text { Skor }\end{array}$ & $\begin{array}{c}\% \\
\text { Capaian }\end{array}$ & Ket \\
\hline F1 (803) & 25 & 125 & 72 & 57,6 & Biasa \\
F2 (956) & 25 & 125 & 78 & 62,4 & Biasa \\
F3 (740) & 25 & 125 & 91 & 72,8 & Suka \\
\hline
\end{tabular}

Sumber: Data Primer, 2019

Pada variabel aroma panelis terlatih memilih formula 2 sebagai formula yang terpilih dengan skor nilai 28 atau $70 \%$ pencapaian. Sementara panelis tidak terlatih memilih formula 3 sebagai formula yang terpilih dengan skor nilai 111 atau $88,8 \%$ pencapaian. Berdasarkan perhitungan skala likert, formula tersebut dinilai sangat disukai.

Tabel 3. Daya terima abon ikan layang oleh panelis tidak terlatih berdasarkan parameter aroma

\begin{tabular}{cccccl}
\hline Formula & $\begin{array}{c}\text { Jumlah } \\
\text { Panelis }\end{array}$ & $\begin{array}{c}\text { Skor } \\
\text { maksimum }\end{array}$ & $\begin{array}{c}\text { Jumlah } \\
\text { Skor }\end{array}$ & $\begin{array}{c}\text { \% } \\
\text { Capaian }\end{array}$ & \multicolumn{1}{c}{ Ket } \\
\hline F1 (803) & 25 & 125 & 64 & 51,2 & Kurang suka \\
F2 (956) & 25 & 125 & 90 & 72 & Suka \\
F3 (740) & 25 & 125 & 111 & 88,8 & Sangat suka \\
\hline
\end{tabular}

Sumber: Data Primer, 2019 
Tabel 4. Daya terima abon ikan layang oleh panelis terlatih berdasarkan parameter aroma

\begin{tabular}{cccccc}
\hline Formula & $\begin{array}{c}\text { Jumlah } \\
\text { Panelis }\end{array}$ & $\begin{array}{c}\text { Skor } \\
\text { maksimum }\end{array}$ & $\begin{array}{c}\text { Jumlah } \\
\text { Skor }\end{array}$ & $\begin{array}{c}\text { \% } \\
\text { Capaian }\end{array}$ & Ket \\
\hline F1 (803) & 8 & 40 & 22 & 55 & Biasa \\
F2 (956) & 8 & 40 & 28 & 70 & Harum \\
F3 (740) & 8 & 40 & 18 & 45 & Agak harum \\
\hline
\end{tabular}

Sumber: Data Primer, 2019

Pada variabel rasa panelis tidak terlatih memilih formula 3 (740) sebagai formula yang terpilih dengan skor nilai 24 atau $60 \%$ pencapaian. Sedangkan panelis tidak terlatih memilih formula 3 (740) sebagai formula yang terpilih dengan skor nilai 98 atau 78,4\% pencapaian. Berdasarkan perhitungan skala likert, formula tersebut dinilai disukai.

Tabel 5. Daya terima abon ikan layang oleh panelis terlatih berdasarkan parameter rasa

\begin{tabular}{cccccc}
\hline Formula & $\begin{array}{c}\text { Jumlah } \\
\text { Panelis }\end{array}$ & $\begin{array}{c}\text { Skor } \\
\text { maksimum }\end{array}$ & $\begin{array}{c}\text { Jumlah } \\
\text { Skor }\end{array}$ & $\begin{array}{c}\% \\
\text { Capaian }\end{array}$ & Ket \\
\hline F1 (803) & 8 & 40 & 18 & 45 & Hambar \\
F2 (956) & 8 & 40 & 24 & 60 & Netral \\
F3 (740) & 8 & 40 & 29 & 72,5 & Gurih \\
\hline
\end{tabular}

Sumber: Data Primer, 2019

Tabel 6. Daya terima abon ikan layang oleh panelis tidak terlatih berdasarkan parameter rasa

\begin{tabular}{cccccc}
\hline Formula & $\begin{array}{c}\text { Jumlah } \\
\text { Panelis }\end{array}$ & $\begin{array}{c}\text { Skor } \\
\text { maksimum }\end{array}$ & $\begin{array}{c}\text { Jumlah } \\
\text { Skor }\end{array}$ & $\begin{array}{c}\text { \% } \\
\text { Capaian }\end{array}$ & Ket \\
\hline F1 (803) & 25 & 125 & 61 & 48,8 & Kurang suka \\
F2 (956) & 25 & 125 & 96 & 78,6 & Suka \\
F3 (740) & 25 & 125 & 108 & 86,4 & Sangat Suka \\
\hline
\end{tabular}

Sumber: Data Primer, 2019

Pada variabel tekstur panelis tidak terlatih memilih formula 3 (740) sebagai formula yang terpilih dengan skor nilai 108 atau $86,4 \%$ pencapaian. Sementara panelis tidak terlatih memilih formula 3 (740) sebagai formula yang terpilih dengan skor nilai 108 atau 86,4\% pencapaian.. Berdasarkan perhitungan skala likert, formula tersebut dinilai disukai.

Tabel 7. Daya terima abon ikan layang oleh panelis terlatih berdasarkan parameter tekstur

\begin{tabular}{cccccc}
\hline Formula & $\begin{array}{c}\text { Jumlah } \\
\text { Panelis }\end{array}$ & $\begin{array}{c}\text { Skor } \\
\text { maksimum }\end{array}$ & $\begin{array}{c}\text { Jumlah } \\
\text { Skor }\end{array}$ & $\begin{array}{c}\text { \% } \\
\text { Capaian }\end{array}$ & Ket \\
\hline F1 (803) & 8 & 40 & 18 & 45 & Kasar \\
F2 (956) & 8 & 40 & 20 & 50 & Kasar \\
F3 (740) & 8 & 40 & 24 & 60 & Netral/biasa \\
\hline
\end{tabular}

Sumber: Data Primer, 2019 
Tabel 8. Daya terima abon ikan layang oleh panelis tidak terlatih berdasarkan parameter tekstur

\begin{tabular}{cccccc}
\hline Formula & $\begin{array}{c}\text { Jumlah } \\
\text { Panelis }\end{array}$ & $\begin{array}{c}\text { Skor } \\
\text { maksimum }\end{array}$ & $\begin{array}{c}\text { Jumlah } \\
\text { Skor }\end{array}$ & $\begin{array}{c}\% \\
\text { Capaian }\end{array}$ & Ket \\
\hline F1 (803) & 25 & 125 & 71 & 56,8 & Biasa \\
F2 (956) & 25 & 125 & 87 & 69,6 & Suka \\
F3 (740) & 25 & 125 & 98 & 78,4 & Suka \\
\hline
\end{tabular}

Sumber: Data Primer, 2019

Secara keseluruhan produk abon ikan layang dapat diterima oleh panelis terlatih dengan pada batas suka. Formula terpilih adalah formula 3 (740) dengan skor persentase $63,75 \%$. Sementara untuk panelis terlatih secara keseluruhan produk abon ikan layang yang dapat diterima pada batas suka. Formula terpilih adalah formula 3 (740) dengan skor persentase $81,86 \%$

\section{PEMBAHASAN}

Berdasarkan penelitian yang telah dilakukan bahwa dari hasil yang diperoleh, diketahui bahwa panelis tidak terlatih rata-rata suka dengan warna formula 3(704), ini dapat dilihat dari nilai yang diperoleh diatas $72,8 \%$ yang artinya masuk kategori disukai atau dapat diterima. Formula ini merupakan formula yang memiliki takaran perbandingan bahan tambahan dan ikan layang bahan paling banyak. Pada panelis terlatih, formula yang terpilih juga formula 3 (740) yaitu kategori warna netral dengan persentase 77,5\%. Dari hasil ini diketahui bahwa dari parameter warna yang dapat diterima atau disukai adalah warna yang antara coklat gelap dan coklat agak terang. Dari Tabel yang telah dijelaskan sebelumnya dapat diketahui bahwa semakin banyak penambahan bahan bumbu, juga akan menyebabkan tingkat kesukaan panelis lebih tinggi terhadap formula.

Terjadinya perbedaan warna diantara formula disebabkan karena jumlah bahan tambahan yang berbeda-beda. Formula 3 (740) yang dinilai warnanya agak kecoklatan oleh panelis terlatih dan yang disukai oleh panelis tidak terlatih karena memiliki jumlah atau takaran bahan tambahan yang lebih tinggi dibandingkan formula lainnya. Warna kuning kecoklatan yang terjadi selama proses penggorengan akibat terjadinya reaksi antara asam amino dan gula pereduks yang disebut reaksi maillard. ${ }^{7}$ Reaksi maillard adalah reaksi pencokelatan non enzimatis yang merupakan reaksi antara protein dengan gula-gula pereduksi yang diawali dengan reaksi gugus amino pada asam amino, peptida atau protein dengan gugus hidroksil glikosidik pada gula. ${ }^{7}$ Rangkaian reaksi diakhiri dengan pembentukan polimer nitrogen berwarna coklat. ${ }^{7}$

Berdasarkan penelitian yang telah dilakukan bahwa dari hasil penilaian oleh panelis yang dilakukan, panelis terlatih memilihi formula 2 (956) dinilai harum dengan persentase $70 \%$, sementara pada panelis tidak terlatih memilih formula 3 sebagai aroma yang paling disukai dengan persentase $88,8 \%$. Hal tersebut dikarenakan penambahan bumbu yang lebih banyak diabanding formula lain menimbulkan aroma yang lebih tajam dibandingkan formula lain .

Timbulnya aroma makanan disebabkan oleh terbentuknya senyawa yang mudah menguap sebagai akibat atau reaksi karena pekerjaan enzim atau dapat juga terbentuk tanpa 
bantuan reaksi enzim. ${ }^{8}$ Begitu pula aroma produk daging berasal dari sejumlah bahan yang ada dalam lemak dan bersifat menguap ketika dipanaskan. ${ }^{8}$ Bumbu yang digunakan dalam pembuatan abon dapat memberikan aroma yang khas. ${ }^{8}$ Bawang merah memiliki bau dan cita rasa yang khas yang ditimbulkan oleh adanya senyawa yang mudah menguap dari jenis sulfur seperti propil sulfur. ${ }^{8}$ Ketumbar dapat memberikan aroma yang diinginkan dan menghilangkan bau amis. ${ }^{8}$

Tekstur adalah tanggapan indera peraba terhadap kehalusan suatu irisan saat disentuh. ${ }^{9}$ Tekstur merupakan salah satu hal yang membedakan abon ikan dengan produk perikanan lainya yaitu berupa serat-serat yang lembut. ${ }^{9}$ Tekstur daging sangat berpengaruh terhadap produk akhir yang dihasilkan dan menentukan tingkat kesukaan kosumen terhadap produk tersebut. ${ }^{9}$ Hal ini diungkapkan pula oleh Adhadinia (2009) dalam Alik, Agustinus Tato' yang menyatakan bahwa tekstur merupakan faktor yang berpengaruh terhadap penilaian, karena tekstur suatu makanan akan terasa saat konsumen memakannya. ${ }^{8}$ Abon ikan pada umumnya memiliki tekstur yang lembut, bumbu-bumbu yang menempel pada daging pada saat diolah dapat menyebabkan tekstur abon menjadi kasar. ${ }^{8}$

Berdasarkan penelitian yang telah dilakukan bahwa pada panelis terlatih menilai tekstur atau kekentalan pada setiap formula berbeda-beda, adapun formula yang dipilih adalah formula tiga (704) yang memiliki tekstur yang biasa dengan persentase $60 \%$. Sedangkan pada panelis tidak terlatih juga memilih formula 3 (704) sebgai formula yang teksturnya paling diskuai dengan persentase $78,8 \%$

Rasa merupakan sensasi yang terbentuk dari hasil perpaduan bahan pembentuk dan komposisinya pada suatu produk makanan atau minuman yang ditangkap oleh indra pengecap. ${ }^{9}$ Rasa menjadi faktor paling penting dalam mengambil keputusan terakhir diterima atau tidaknya suatu produk. ${ }^{9}$ Walaupun warna, aroma, tekstur baik namun apabila rasanya tidak enak maka konsumen akan menolak produk tersebut. ${ }^{9}$

Berdasarkan penelitian yang telah dilakukan bahwa hasil analisis pada parameter rasa dari panelis terlatih menilai formula yang terpilih adalah formula 3 yang memiliki rasa gurih dengan persentase $72,5 \%$. Sementara itu pada tingkat kesukaan, panelis tidak terlatih juga memilih formula 3 sebagai formula yang sangat disukai dengan persentase $86,4 \%$. Penambahan bumbu dengan takaran yang lebih banyak dari formula lainnya merupakan salah satu sebab yang menyebabkan rasa abon ikan lebih gurih dan lebih terasa asin.

\section{KESIMPULAN}

Berdasarkan hasil penelitian ini dapat disimpulkan bahwa semua formula abon ikan layang dapat diterima oleh panelis namun formula 3 lebih dominan tingkat penerimaannya. Adapun untuk formula terpilih yang akan diuji secara lanjut dengan uji kandungan zat gizi makro dan mikro, uji kandungan omega 3 dan uji daya simpan adalah formula 3 dengan mempertimbangkan hasil dari panelis terlatih dan tidak terlatih. Produk terpilih masih memiliki banyak kekurangan diantaranya tekstur yang belum terlalu kering, sehingga diharapkan ada penelitian selanjutnya yang berbasis abon agar lebih diperhatikan antara kandungan air pada bahan baku, jumlah bumbu dan lamanya proses pengolahan pada produk. 


\section{DAFTAR PUSTAKA}

1. Wahyono, H. Dkk., Potensi Cincau Hitam Sebagai Pangan Fungsional Untuk Kesehatan. Jurnal Pangan dan Agroindustri. 2015; 3(3):957-61

2. Permenkes. Tentang Pencantuman Kandungan Gula, Garam, Dan Lemak Serta Pesan Kesehatan Untuk Pangan Olahan Siap Saji. Jakarta: Kementrian Kesehatan;2013

3. Suryastiri, N.M., Diversifikasi Konsumsi Pangan Pokok Berbasis Potensi Lokal Dalam Mewujudkan Ketahanan Pangan Rumah Tangga Pedesaan Di Kecamatan Semin Kabupaten Gunung Kidul. Jurnal Pembangunan Ekonomi. 2008;13(1):51-60

4. Winarti, C \& Nurdanah, N., Peluang Tanaman Rempah Dan Obat Sebagai Sumber Pangan Fungsional. Jurnal Litbang Pertanian. 2005;24(12):47-55

5. Arlinda \& Dara, W., Mutu Organoleptik Dan Kimia Abon Ikan Gabus Yang Disubstitusi Sukun. Jurnal Katalisator Kopertis Wilayah X Kementrian Riset Teknologi Dan Pendidikan Tinggi. 2017;2(2):61-6

6. Mutyia., Daya Terima Produk Minuman Jelly dan Serbuk Minuman Instan Labu Siam. Skripsi. Fakultas Kesehatan Masyarakat Universitas Hasanuddin. Makassar:2016.

7. Mustar., Studi Pembuatan Abon Ikan Gabus (Ophiocephalus Striatus) Sebagai Makanan Suplemen (Food Suplement). Skripsi. Makassar: Fakultas Pertanian Universitas Hasanuddin:2013

8. Alik, Agustinus Tato', Dkk,. "A Study On Consumer Acceptance Of Tilapia Abon (Oreochromis niloticus) With the Addition White Oyster Mushroom (Pleurotus ostreatus)". Fakultas Sains Universitas Riau.

9. Sulthoniyah, Siti, dkk., Pengaruh Suhu Pengukusan Terhadap Kandungan Gizi dan Organoleptik Abon Ikan Gabus (Ophiocephalus striatus). THPi Student Journal, 2013;1 (1):33-45. 